\title{
"Voltai para mim e eu voltarei para vós": um estudo exegético de Jl 2,12-18
}

\author{
Orientador: Leonardo Agostini Fernandes \\ Mestranda: Jane Maria Furghestti Lima \\ Área de Concentração: Teologia Bíblica
}

Linha de Pesquisa: Análise e Interpretação de Textos do Antigo e Novo Testamento

O livro de Joel poder ser considerado uma unidade teologicamente unificada dentro da literatura profética por causa da temática do yôm YHWH. O contexto de Jl 2,12-18 é de uma catástrofe natural que provoca a carestia e ausência dos produtos necessários para subsistência. Diante desta situação de crise, o povo de Judá-Jerusalém vive uma condição de apatia espiritual. Ainda há, no entanto, esperança de que por meio de uma ação litúrgica se possa mudar este contexto desfavorável. O profeta, então, seguindo a convocação de YHWH, interpela a comunidade para que ela possa fazer o processo de retorno a Ele.

É neste contexto que se desvela o tema do yôm YHWH. Este yôm não é considerado uma ameaça para o bem estar da comunidade. Ao contrário, o yôm YHWH é interpretado como um dia de salvação para Judá-Jerusalém, porque YHWH é um refúgio e uma proteção para seu povo.

O chamado do profeta para retornar a YHWH é interpretado como uma convocação para o povo honrá-lo, demonstrando uma renovada lealdade e confiança com gestos sinceros demonstrados por ritos religiosos.

O sentido último deste retorno para YHWH não se refere aos pecados do povo. Este retorno expressa o desejo sincero de retornar e ouvir a palavra de YHWH, novamente, numa situação de aflição. Neste contexto, retomada a relação de comunhão entre a comunidade e YHWH, o povo aceita a oferta da graça divina e retorna para Ele, com todo seu coração. YHWH não somente restaura os bens materiais a seu povo, mas oferece seu coração e seu próprio ser. Ele retorna para Judá-Jerusalém, enquanto seu povo também retorna a Ele.

Palavras-chave: Teologia Bíblica; Exegese do AT; Literatura Profética. 